also possible. There is a paper from the Netherlands on the use of a mixture of cassava, soya and glyceryl monostearate, and one from Sweden on bread made from tef, a grain extensively used in Ethiopia.

Bread is convenient and it gains prestige from its importance in the industrialized countries, it is therefore gradually ousting gruels and porridges in developing countries. This is unfortunate, for these ancient forms of food can be made from a very extensive range of seeds, they lend themselves readily to fortification, and they can be made from grains that, by parboiling and in other ways, have been given an extended shelf life and have suffered less than ordinary grains from loss of vitamins and minerals during milling. Pence describes the history and present status of some of these products.

Anybody connected with the production and introduction of novel foods is repeatedly told that it is nearly impossible to change people's food habits. A moment's reflexion on the changes in our own food habits during the past half century shows that this is untrue. It is equally untrue elsewhere. There are papers here by Parpia, De Muelenaere, Shaw, Dimino, Kapsiotis and Wickström on successes with unfamiliar protein-rich foods in India, South Africa, Guatemala, Colombia, North Africa and Ethiopia. There have been failures elsewhere. It is not always possible to be sure about the reasons for them but various suggestions are made and this collection of thirty-three articles ends with the encouraging forecast that these mistakes can be avoided in future. Anybody who is concerned, or is likely to be concerned, with the introduction of novel foods intended to counteract nutritional deficiencies should study these articles. Awareness that beneficial changes have been made is an important step in gaining the confidence on which further innovation depends. Conservative prejudice is undoubtedly an obstacle to innovation: the prejudice of officials is more obstructive than the prejudice of consumers. These case-histories will help to give innovators the confidence needed to overcome prejudice in either camp.

N. W. Pirie

\section{CONSISTENT BEHAVIOUR}

The Behaviour of Domestic Animals

Edited by E. S. E. Hafez. Second edition. Pp. xii + $647+22$ plates. (Baillière, Tindall and Cassell: London, August 1969.) 120s.

IN 1962, Professor E. S. E. Hafez of Washington State University produced, with the aid of an editorial board and a large number of contributors, an encyclopaedic work entitled The Behaviour of Domestic Animals. In doing this he broke entirely new ground and the success of the publication has given clear evidence of his prescience, editorial skill and wide knowledge. The book has indeed become a necessity on the shelves of all those concerned with the behavioural principles involved in the commercial utilization, by domestication, of mammals, birds and their products. It is a remarkable tribute to the work that a new edition should be required after seven years.

This new edition is in several ways a better and more balanced book than its forerunner, and includes a fair amount of material such as that on neural and endocrine mechanisms of behaviour, and on early experience, which was lacking in the 1962 production. This has been accomplished and the work in general brought fairly well up to date without substantially increasing its size. Half of the original twenty-four contributors to the first volume have, for various reasons, dropped out in the new edition and new authors have been brought in to make up the new total to twenty-six. The general design of the work is very similar but the original chapter on behavioural pharmacology has been omitted and a greatly extended chapter on physiological analysis of animal behaviour has taken up the available space by enlarging and modifying the older chapter entitled "Physiological Mechanisms and Behaviour Patterns". This in general seems to be a good change because behavioural pharmacology is rather marginal from the point of view of the presumed spectrum of readership of the book. The useful little chapter by E. B. Hale on comparative behaviour, with which the earlier book ended, is omitted in the new version. This, however, is perhaps a sensible move because the earlier chapter was hardly large enough to be very effective and the available space has been well used elsewhere.

The chapters in parts three and four, which deal seriatim with the main animals and birds domesticated, on the whole fulfil their function excellently. The editor is, indeed, to be congratulated on having secured such consistency from such a large team of associates. The volume is well presented and illustrated and the price, in view of present-day costs and the size of the work is, perhaps not excessive--though one would have hoped that the large potential sale of such a volume might have justified something lower.

W. H. THORPE

\section{FOCAL PHOBIAS}

\section{Fears and Phobias}

By Isaac M. Marks. Pp. 302. (Heinemann (Medical): London, June 1969.) $45 s$.

THIs book has a narrower scope than its title and preface suggest. It discusses fears and phobias largely in behaviourist terms after a rambling first section emphasizing innate factors. Marks concludes that desensitization is the best available treatment for focal phobias in patients without other symptoms, admittedly a small minority of those people who feel handicapped by excessive fearfulness. He rejects Eysenck's canard that two-thirds of neurotics get better by themselves, acknowledging the rarity of spontaneous improvement in the commonest group of people who seek help for their fearfulnessthose with varying and multiple fears, panic attacks, depressions, feelings of depersonalization, and the pattern of fearful constriction of living he calls agoraphobia. This important group gets some help from desensitization therapy, but the studies cited show that results are not significantly better than brief psychotherapy. When it does help, desensitization leads to change in the symptom alone, a debatable measure of change. Marks believes that it is complementary to psychotherapy at times.

In his review of the literature on aetiology, the very sketchy treatment he gives Harlow's work exemplifies the author's selective interest. He does not include the evidence that the quality of maternal care in infancy strongly influences later fearfulness. Without considering this factor, it is hard to make sense of the fact that "agoraphobics" feel a sense of safety "in the presence of a trusted companion, be this human, animal, or inanimate".

The book does provide a good deal of information about desensitization, the approach with which the author seems most familiar. His discussion of psychoanalysis and psychotherapy based on it is limited to a few pages. Much more would need to be said to cover the subject in contemporary terms than the author's superficial dis. cussion of phobias as a symbolic façade for other fears and conflicts "and that the task of psychotherapy is to uncover these, upon which the phobias will resolve". A serious evaluation of the psychoanalytic approach must get beyond cocktail party Freudianism. The book is repetitive and needs careful editing. My strongest objection is to the distant stance from which fearful people are viewed; they are stick figures, not persons.

Leonard J. Friedman 